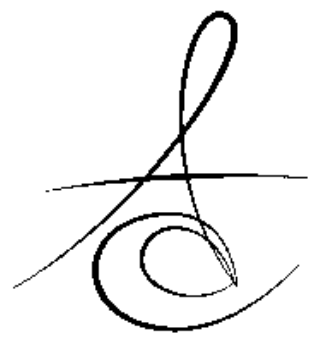

\title{
ÇENELERDE GÖRÜLEN İNTRAOSSEÖZ LEZYONLARIN KLİNİK VE RADYOLOJİK BULGULARININ DEĞERLENDİRİLMESİ
}

\section{THE EVALUATION OF CLINICAL AND RADIOLOGICAL FINDINGS OF INTRAOSSEOUS JAW LESIONS}

\author{
Dr. İbrahim Şevki BAYRAKDAR* \\ Prof. Dr. Ahmet Berhan YILMAZ* \\ Doç. Dr. Fatma ÇAĞLAYAN* \\ Prof. Dr. Ümit ERTAŞ ${ }^{* *}$
}

Prof. Dr. Cemal GÜNDOĞDU ${ }^{* * *}$

\begin{abstract}
Makale Kodu/Article code: 2466
Makale Gönderilme tarihi: 11.11 .2015

Kabul Tarihi: 17.11.2015
\end{abstract}

\section{ÖZET}

Amaç: Bu çalışmanın amacı; çenelerde görülen litik kemik içi lezyonların sıklıklarını, dağılımlarını, rutin klinik ve direkt radyografilerle yapılan rutin radyolojik muayene bulgularını sunmak ve çenelerde görülen kemik içi patolojilerin tespitinde, ayırıcı tanısında ve tedavi planlamasında rutin klinik ve radyolojik muayenenin önemini vurgulamaktır.

Gereç ve yöntemler: Bu çalışmada; 112 hastada tespit edilen 123 adet litik kemik içi çene lezyonunun klinik ve radyolojik muayene bulguları değerlendirildikten sonra lezyondan elde edilen biyopsi materyali patoloji laboratuarına gönderilerek histopatolojik değerlendirme yapılmıştır. Histopatolojik olarak tanı konulan lezyonlar; kistler-tümör ve benzeri lezyonlar olmak üzere iki grup altında sınıflandırılıktan sonra, bu iki gruba ait lezyonların rutin klinik ve radyolojik bulguları değerlendirilmiştir.

Bulgular: Çalışmamızda değerlendirilen 123 lezyonun $74(\%$ 60,2) tanesi kist, $49(\% 39,8)$ tanesi tümör ve benzeri lezyondu. En çok rastlanılan kist radiküler kist, en çok rastlanılan tümör ve benzeri lezyon ise; keratokistik odontojenik tümördü. Lezyonların cinsiyete, yaş gruplarına ve bulundukları çeneye göre dağılımları değerlendirildiğinde istatistiksel olarak anlamlı bir farklılık belirlenemezken $(p>0,05)$, lokasyona göre dağılımlarında istatistiksel olarak anlamlı bir farklılık olduğu saptanmış ve posterior bölge yerleşiminin daha fazla olduğu belirlenmiştir $(p<0.001)$. Ağrı ve lezyonla ilişkili dişlerde vitalite kaybı en çok rastlanılan bulgulardı.

Sonuç: Çene kemiklerinde sıklıkla görülen intraosseöz lezyonların tespitinde, ayırıc tanısında ve tedavi planlamasında klinik muayene ve direkt radyografilerle yapılan radyolojik muayenenin önemli bir yeri vardır. Çenelerde rutin muayene sonucu elde edilen bulgularla tesadüfi olarak kemik patolojileri tespit edilebilir. Bu sebeple diş hekimleri rutin klinik ve radyolojik muayenenin önemi konusunda bilinçli olmalıdırlar.

Anahtar Kelimeler: çene patolojileri, muayene, direkt radyografi

\section{ABSTRACT}

Aim: The purpose of this study was to determine the frequency, distribution, and routine clinical and radiological findings of intraosseous jaw lesions. Furthermore, we aimed to emphasize the importance of routine clinical and radiological examinations in the diagnosis and treatment of intraosseous jaw lesions.

Materials and methods: A total of 123 lytic intraosseous jaw lesions diagnosed from 112 patients were evaluated for their clinical and radiological findings. After the examinations, the biopsy specimens were sent to the pathology laboratory, and histopathological examinations of the biopsied specimens were made. Considering the histopathological evaluations, the lesions were classified into two groups: cysts or tumors and tumor-like lesions. The findings from the lesions in these two groups were then assessed.

Results: Of the 123 lesions, 74 (60.2\%) were cysts and $49(39.8 \%)$ were tumors and tumor-like lesions. The most common cyst was the radicular cyst, and the most common tumor and tumor-like lesion was the keratocystic odontogenic tumor. There was no significant distribution of lesions with regard to sex, age, and jaw ( $p>0.05)$. However, there was a significant distribution of lesions with regard to their location $(p<0.001)$, which was mostly in the posterior region. Pain and loss of vitality in the teeth were associated with the lesions and were the most frequent findings.

Conclusion: Clinical and radiological examinations made with direct radiography were important in the detection, differential diagnosis, and treatment planning of intraosseous jaw lesions. Incidentally, bone lesions in the jaw can be determined through routine examinations. Therefore, dentists should be aware of the importance of routine clinical and radiological examinations.

Keywords: jaw pathologies, examination, direct radiography

\footnotetext{
* Atatürk Üniversitesi Diş Hekimliği Fakültesi Ağız, Diş ve Çene Radyolojisi AD

** Atatürk Üniversitesi Diş Hekimliği Fakültesi Ağız, Diş ve Çene Cerrahisi AD

${ }^{* * *}$ Atatürk Üniversitesi Tıp Fakültesi Tıbbi Patoloji AD 
Atatürk Üniv. Diş Hek. Fak. Derg.

J Dent Fac Atatürk Uni

Cilt:25, Sayı:3, Yıl: 2015, Sayfa: 281-288
BAYRAKDAR, YILMAZ, ÇAĞLAYAN, ERTAŞ, GÜNDOĞDU

\section{GİRIŞ}

Çeneler; odontojenik ve odontojenik kaynaklı olmayan kemik içi patolojilerin sıklıkla görüldüğü anatomik bölgelerdir. Odontogenezis olayının bu bölgede gerçekleşmesi sebebiyle, diş gelişiminin farklı safhlarından orijin alan kist ve tümörler bu bölgede sıklıkla görülmesine rağmen, diğer neoplastik ve neoplastik olmayan kemik lezyonları da bu bölgede sıkça görülmektedir. ${ }^{1}$ Çenelerde görülen bu lezyonların çok geniş çeşitlilik göstermesinden ötürü; çenelerde görülen kemik lezyonlarının tanısı zordur. ${ }^{2,3}$ Klinik muayene ve ardından direkt radyografik tekniklerle elde edilen radyografilerle yapılan rutin radyolojik muayene kemik içi çene lezyonlarının tanı ve tedavi planlamasında öncelikli olarak başvurulan yöntemlerdir. Çenelerinde kemik içi lezyona sahip hastalarda klinik muayene sonucunda; ağrı, şişlik, fistül, lenfadenopati, ağız açıklığında kısıtııık, palpasyonda hassasiyet, fasiyal asimetri, lezyonla ilişkili dişlerde mobilite, vitalite kaybı gibi bulgular tespit edilebilirken, intraoral ve ekstraoral direkt radyografilerle yapılan rutin radyolojik muayene sonucunda; lezyonun lokasyonu, sınırları, boyutu, çevre kemik dokusu ile olan ilişkisi, lezyonla ilişkili dişlerde kök rezorpsiyonu, yer değişikliği ve lezyon içerisinde gömük diş olup olmadığı hakkında bilgi elde edilebilir. $\mathrm{Bu}$ bulgular çene patolojilerinin tespiti, ayırıcı tanısı ve tedavi planlamasında klinisyenlere yardımcı olabilir., ${ }^{4,5}$

$\mathrm{Bu}$ çalışmanın amacl; çenelerde görülen litik kemik içi lezyonların sıklıklarını, dağılımını, rutin klinik ve direkt radyografilerle yapılan rutin radyolojik muayene bulgularını sunmak ve çenelerde görülen kemik içi patolojilerin tespitinde, ayırıcı tanısında ve tedavi planlamasında rutin klinik ve radyolojik muayenenin önemini vurgulamaktır.

\section{GEREÇ VE YÖNTEMLER}

2013-2015 yılları arasında Atatürk Üniversitesi Diş Hekimliği Fakültesi Ağız, Diş ve Çene Radyolojisi (ADÇR) Anabilim Dalında yürütülen bu araştırmanın bilimsel etik kurallara uygunluğu, Atatürk Üniversitesi Diş Hekimliği Fakültesi Etik Kurul Başkanlığı tarafından onaylanmış ve hastalara bilgilendirmiş olur formu imzalatılmıştır. Bu çalışmaya; kliniğimizde rutin klinik ve radyolojik muayene sonucunda, çene kemiklerinde rezorpsiyona sebep olan, radyografik olarak tamamen radyolüsent ya da radyolüsent-radyoopak görünümlü, mikst lezyonlara sahip olduğu tespit edilen hastalar dâhil edilmiştir. Hastaların çalışmaya dâhil edilmesinde herhangi bir yaş grubu ya da cinsiyet farkı göz önünde bulundurulmamıştır.

Çalışmaya dâhil edilen hastaların yaş, cinsiyet gibi demografik özellikleri kaydedildikten sonra ekstraoral ve intraoral klinik muayene ve ardından panoramik radyografi, periapikal radyografi ve okluzal radyografi gibi direkt radyografik tekniklerle elde edilen radyografilerle yapılan rutin radyografik muayene sonucunda hastanın ağrı, şişlik, fistül, lenfadenopati, ağız açıklığında kısıtııık, palpasyonda hassasiyet, fasiyal asimetri, parestezi, lezyonla ilişkili dişlerde mobilite, yer değiştirme, vitalite kaybı, kök rezorpsiyonu ve lezyonla ilişkili gömük diş gibi bulgulara sahip olup-olmadığı kaydedilmiştir. Daha sonra hastalar biyopsi alınması maksadıyla fakültemiz Ağız, Diş ve Çene Cerrahisi bölümüne sevk edilmiştir. Hastalardan elde edilen biyopsi materyali patoloji laboratuarına gönderilmiştir ve mikroskobik olarak uzman medikal patolog tarafından histopatolojik değerlendirme yapılmıştır. Histopatolojik olarak tanı konulan lezyonlar; kistler ile tümör ve benzeri lezyonlar olmak üzere iki grup altında sınıflandırılmıştır. Bu çalışmada; KOT vakaları, KOT epitelinde benign bir tümörle uyumlu, kendiliğinden bir büyüme potansiyelinin mevcut olması ve KOT'ün Dünya Sağlık Örgütü (WHO) tarafından 2005 yılında yapılan sınıflamada benign odontojenik tümörler içerisinde yeniden sınıflandırılmasından ötürü tümör ve benzeri lezyonlar grubuna dâhil edilmiştir. İltihabi granülasyon dokusu vakaları; solid bir lezyon olma özelliğinden ötürü tümör ve benzeri lezyonlar grubuna, stafne kemik kavitesi ve travmatik kemik kisti gibi yalancı kist vakaları ise; gerçek kistik lezyonlar olmamalarına rağmen, radyografik özellikleri göz önüne alınarak kist grubu lezyonlar içerisine dâhil edilmiştir. Daha sonra bu iki grubu oluşturan lezyonların rutin klinik ve radyolojik bulguları değerlendirilmiştir.

\section{BULGULAR}

Çalışmamızda; 112 hastada tespit edilen, 123 kemik içi lezyon değerlendirilmiştir. Çalışmaya dâhil edilen bireylerin 72 (\% 64.3) tanesinin erkek, 40 (\% 35.7) tanesinin kadın olduğu belirlenmiştir. Bireylerin yaşlarının 6-72 yaş arasında değişmekte olduğu ve yaşlarının ortalamasının $31.7 \pm 15.4$ olduğu tespit edilmiştir. 
Çalışmamıza dâhil edilen lezyonların 74 (\% 60.2) tanesinin kist, 49 (\% 39.8) tanesinin tümör ve benzeri lezyonlardan oluştuğu belirlenmiştir. Kistlere 664 yaş arası hastalarda, tümör ve benzeri lezyonlara ise; 7-72 yaş arası hastalarda rastlanılmışır.

Kistlerin dağıımı değerlendirildiğinde, 53 (\% 71.6) adet radiküler kiste, 6 (\% 8.1) adet dentigeröz kiste, 5 (\% 6.8) adet stafne kemik kavitesine, 3 (\% 4.1), adet insiziv kanal kistine, 3 (\% 4.1) adet travmatik kemik kistine, 2 (\% 2.7) adet rezidüel kiste ve 2 (\%2.7) adet lateral periodontal kiste rastlanıldığı tespit edilmiştir.
Tümör ve benzeri lezyonların dağııımı değerlendirildiğinde, $30(\% 61,2)$ adet keratokistik odontojenik tümöre (KOT), $10 \quad\left(\begin{array}{ll}\% & 20,4)\end{array}\right)$ adet dev hücreli granülomaya, $3(\% \quad 6,1)$ adet iltihabi granülasyon dokusuna, 2 (\% 4,1) adet ossifying fibromaya, 2 (\% 4,1) adet ameloblastomaya, 1 (\% 2) adet adenomatoid odontojenik tümöre ve $1\left(\begin{array}{ll}\% & 2\end{array}\right)$ adet fibröz displaziye rastlanıldığı tespit edilmiştir.

Çalışmaya dâhil edilen lezyonların cinsiyete, yaş gruplarına ve bulundukları çeneye göre dağıımları değerlendirildiğinde istatistiksel olarak anlamlı bir farkllık belirlenemezken $(p>0,05)$, lokasyona göre dağlımlarında istatistiksel olarak anlamlı bir farklıık olduğu saptanmış ve posterior bölge yerleşiminin daha fazla olduğu belirlenmiştir $(p<0.001)$. (Tablo- 1,2$)$

Tablo 1. Cinsiyet ve yaşa göre lezyonların dağılımı

\begin{tabular}{|c|c|c|c|c|c|c|c|c|c|c|c|c|c|c|c|c|c|c|c|c|c|c|c|}
\hline & \multirow{3}{*}{ Lezyon Tipi } & \multicolumn{10}{|c|}{ Erkek } & \multicolumn{10}{|c|}{ Kadın } & \multirow{2}{*}{\multicolumn{2}{|c|}{$\begin{array}{l}\text { Topla } \\
\text { m }\end{array}$}} \\
\hline & & \multicolumn{2}{|c|}{$6-20$} & \multicolumn{2}{|c|}{$21-30$} & \multicolumn{2}{|c|}{$31-40$} & \multicolumn{2}{|c|}{$41-50$} & \multicolumn{2}{|c|}{$51-72$} & \multicolumn{2}{|r|}{$6-20$} & \multicolumn{2}{|c|}{$21-30$} & \multicolumn{2}{|c|}{$31-40$} & \multicolumn{2}{|c|}{$41-50$} & \multicolumn{2}{|c|}{$51-72$} & & \\
\hline & & $\mathrm{n}$ & $\%$ & $\mathrm{n}$ & $\%$ & $n$ & $\%$ & $\mathrm{n}$ & $\%$ & $\mathrm{n}$ & $\%$ & $\mathrm{n}$ & $\%$ & $\mathrm{n}$ & $\%$ & $\mathrm{n}$ & $\%$ & $\mathrm{n}$ & $\%$ & $\mathrm{n}$ & $\%$ & $\mathrm{n}$ & $\%$ \\
\hline \multirow{7}{*}{ 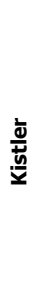 } & Radiküler Kist & 11 & 55 & 10 & 55,6 & 8 & 44,4 & 5 & 41,7 & 3 & 23,1 & 7 & 38,9 & 6 & 50 & 1 & 50 & - & - & 2 & 25 & 53 & 43,1 \\
\hline & Dentigeröz Kist & 1 & 5 & 3 & 16,7 & 1 & 5,6 & - & - & - & - & 1 & 5,6 & - & - & - & - & - & - & - & - & 6 & 4,9 \\
\hline & Stafne Kemik Kavitesi & - & - & 1 & 5,6 & 1 & 5,6 & 1 & 8,3 & 2 & 15,4 & - & - & - & - & - & - & - & - & - & - & 5 & 4,1 \\
\hline & İnsiziv Kanal Kisti & - & - & - & - & - & - & - & - & 1 & 7,7 & 1 & 5,6 & - & - & - & - & - & - & 1 & 12,5 & 3 & 2,4 \\
\hline & Rezidüel Kist & - & - & - & - & - & - & - & - & 1 & 7,7 & - & - & - & - & - & - & - & - & 1 & 12,5 & 2 & 1,6 \\
\hline & Travmatik Kemik Kisti & - & - & - & - & - & - & - & - & - & - & 2 & 11,1 & 1 & 8,3 & - & - & - & - & - & - & 3 & 2,4 \\
\hline & Lateral Periodontal Kist & - & - & - & - & 1 & 5,6 & - & - & - & - & - & - & 1 & 8,3 & - & - & - & - & - & - & 2 & 1,6 \\
\hline \multirow{7}{*}{ 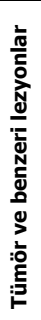 } & $\begin{array}{l}\text { Keratokistik } \\
\text { Odontojenik Tümör }\end{array}$ & 4 & 20 & 4 & 22,2 & 5 & 27,8 & 6 & 50 & 5 & 38,5 & 1 & 5,6 & 2 & 16,7 & - & - & 1 & 50 & 2 & 25 & 30 & 24,4 \\
\hline & Dev Hücreli Granülom & 1 & 5 & - & - & 1 & 5,6 & - & - & - & - & 3 & 16,7 & 2 & 16,7 & - & - & 1 & 50 & 2 & 25 & 10 & 8,1 \\
\hline & $\begin{array}{l}\text { İltihabi Granülasyon } \\
\text { Dokusu }\end{array}$ & 3 & 15 & - & - & - & - & - & - & - & - & - & - & - & - & - & - & - & - & - & - & 3 & 2,4 \\
\hline & $\begin{array}{l}\text { Adenomatoid } \\
\text { Odontojenik Tümör }\end{array}$ & - & - & - & - & - & - & - & - & - & - & 1 & 5,6 & - & - & - & - & - & - & - & - & 1 & 0,8 \\
\hline & Ameloblastoma & - & - & - & - & - & - & - & - & 1 & 7,7 & - & - & - & - & 1 & 50 & - & - & - & - & 2 & 1,6 \\
\hline & Fibröz Displazi & - & - & - & - & - & - & - & - & - & - & 1 & 5,6 & - & - & - & - & - & - & - & - & 1 & 0,8 \\
\hline & Ossifying Fibroma & - & - & - & - & 1 & 5,6 & - & - & - & - & 1 & 5,6 & - & - & - & - & - & - & - & - & 2 & 1,6 \\
\hline & Toplam & 20 & 100 & 18 & 100 & 18 & 100 & 12 & 100 & 13 & 100 & 18 & 100 & 12 & 100 & 2 & 100 & 2 & 100 & 8 & 100 & 123 & 100 \\
\hline
\end{tabular}


Atatürk Üniv. Diş Hek. Fak. Derg.

J Dent Fac Atatürk Uni

Cilt:25, Sayı:3, Yıl: 2015, Sayfa: 281-288

Tablo 2. Lezyonların bulundukları çene ve lokasyonlarına göre dağılımları

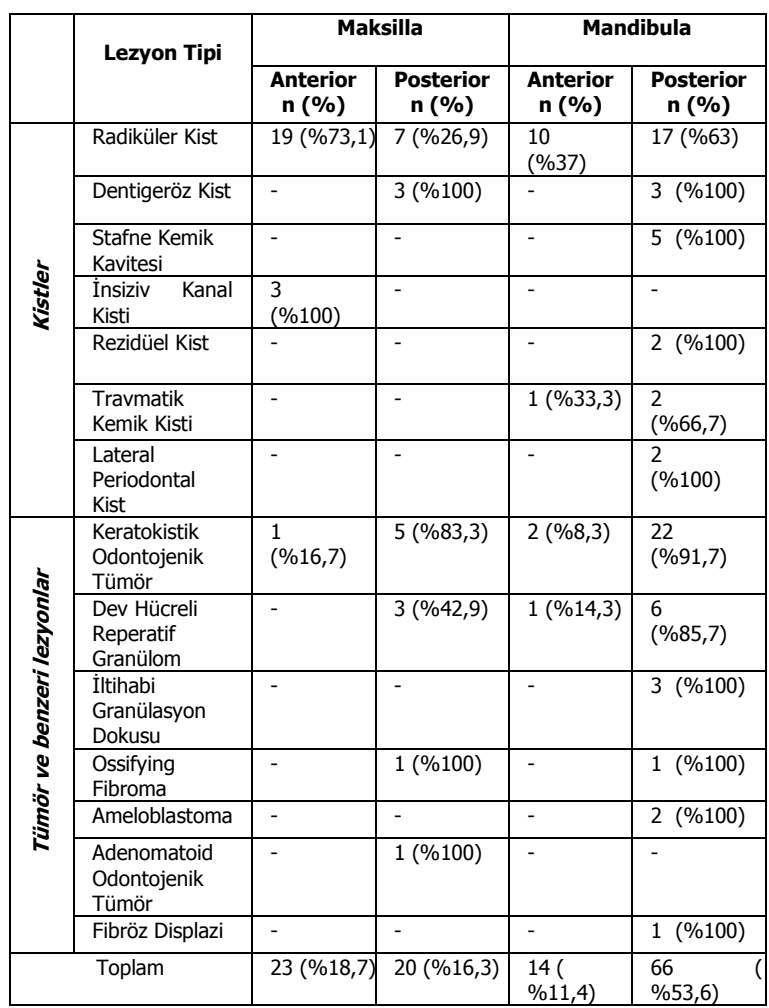

n: Hasta sayısı \%: Yüzdelik oran

Çalışmamızda tespit edilen lezyonların rutin klinik ve radyolojik muayene bulgularını değerlendirdiğimizde; 123 lezyonun 75 (\% 61,0) tanesinin hastaların şikâyetleri sonucunda tespit edildiği, 48 (\% 39) tanesinin ise tesadüfi olarak rutin klinik ve radyolojik muayene sonucunda tespit edildiği belirlenmiştir. Bu lezyonlar içerisinde; 74 adet kistin 31 (\% 41,9) tanesi; 49 adet tümör ve benzeri lezyonun ise; 17 (\% 34,7) tanesi rutin klinik ve radyolojik muayene sonucunda tesadüfi olarak tespit edilmiştir.

Çalışmamıza dâhil edilen lezyonların rutin klinik ve radyolojik muayene bulguların değerlendirdiğimizde; lezyonların 65 (\% 52.8) tanesinin ağrıya, 40 (\% 32.5) tanesinin şişliğe, 16 (\% 13) tanesinin fistüle, 1 (\% 0.8) tanesinin lenfadenopatiye, 2 (\% 1.6) tanesinin ağız açıklığında kısıtlıı̆a, 43 (\% 35$)$ tanesinin palpasyonda hassasiyete, 20 (\% 16.3) tanesinin fasiyal asimetriye, 8 (\% 6.5) tanesinin paresteziye, 23 (\% 18.7) tanesinin lezyonla ilişkili dişlerde mobiliteye, 12 (\% 9.8) tanesinin lezyonla ilişkili dişlerde yer
BAYRAKDAR, YILMAZ, ÇAĞLAYAN, ERTAŞ, GÜNDOĞDU

değiş̧irmeye, 66 (\% 53.7) tanesinin lezyonla ilişkili dişlerde vitalite kaybına, 10 (\% 8.1) tanesinin lezyonla ilişkili dişte kök rezorpsiyonuna sebep olduğu belirlenirken, 25 (\% 20.3) tanesinin içerisinde gömük diş varlığı tespit edilmiştir. (Şekil-1,2) Bu bulguların kistler ile tümör ve benzeri lezyonlarda görülme oranları Şekil-3'deki çubuk grafiğinde özetlenmiştir.

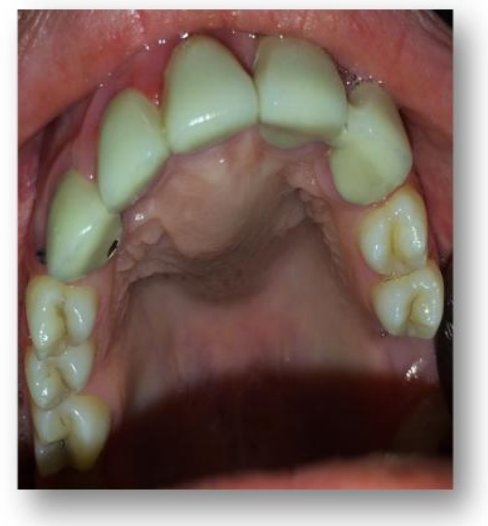

Şekil-1. Anterior bölgede yer alan lezyon sebebiyle damakta meydana gelen şişlik

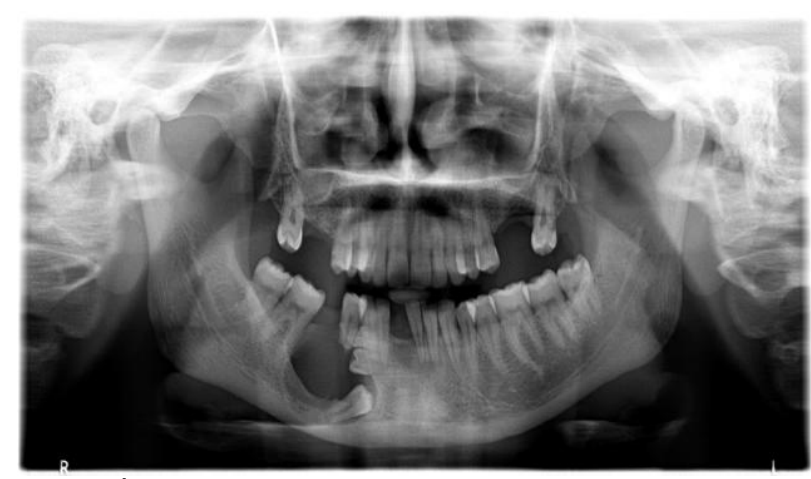

Şekil-2. İçerisinde gömük diş barındıran, komşu dişlerde kök rezorpsiyonu ve yer değiştirmeye sebep olan litik lezyon alanı 


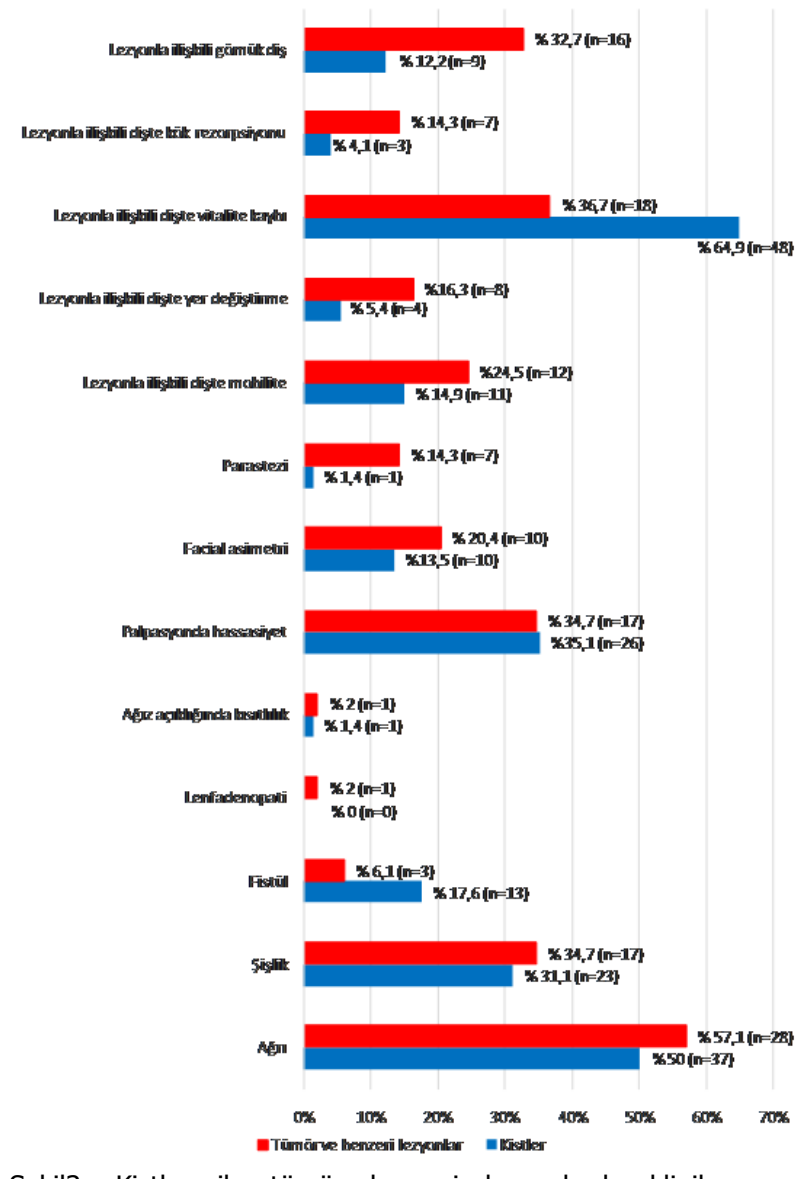

Şekil3. Kistler ile tümör benzeri lezyonlarda klinik ve radyolojik muayene bulgularının görülme oranları

\section{TARTIŞMA}

Çeneler; diş dokularından, kemikten, sinirlerden ya da vasküler yapılar gibi farklı dokulardan köken alan patolojilerin sıklıkla görüldüğü anatomik bölgelerdir. Odontojenik ve odontojenik kaynaklı olmayan kistler ile tümörler, enflamatuar çene lezyonları, metabolik ve genetik hastalıklar sonucu çenelerde oluşan patolojik durumlar ve maligniteler gibi çok geniş bir yelpaze içerisinde değerlendirilebilecek kemik içi çene lezyonları; etiyolojileri, histopatolojik özellikleri, radyografik karakteristikleri gibi özelliklerine göre çok farklı sınıflandırmalara tabi tutulmuştur. Bu lezyonların çeşitliliğinin çok fazla olması ve benzer klinik-radyolojik özelliklere sahip olmalarından dolayı tanıları zordur. ${ }^{6}$ Rutin olarak yapılan klinik ve radyolojik muayene bu lezyonların tespitinde, ayırıc tanısında ve tedavi planlamasında önemli bilgiler sağlar.

$\mathrm{X}$ ışınının tıpta kullanımasından beri radyografik görüntü çene lezyonlarının tanı, tedavi ve tedavi sonrası takip süreçlerinde çok önemli bir yere sahiptir. Radyolojik değerlendirmede kullanılan ilk yöntem genellikle direkt radyografilerdir. Periapikal radyografi, okluzal radyografi gibi intraoral radyografi yöntemleri ve panoromik radyografi gibi ekstraoral radyografiler çene lezyonlarının tespiti ve değerlendirilmesinde, radyolojik değerlendirmenin ilk basamağında kullanılabilecek görüntüleme yöntemleridir. Bu radyografik yöntemlerinin başlıca avantajları, dişler ve destek yapıları ile fasiyal kemik yapının geniş bir alanının görüntülemesini kolay bir şekilde ve düşük radyasyon dozuyla elde edebilmesidir. 4, 7, 8 Bu avantajlarına rağmen; düşük çözünürlük, magnifikasyon, distorsiyon gibi kısıtlılıkları ve iki boyutlu bir görüntü sağlamalarından ötürü rutin radyografik yöntemler her lezyonun varlığını güvenli bir şekilde tespit edemeyip, lezyonun anatomik yapılarla olan ilişkisini ve gerçek boyutunu tam olarak ortaya koyamayabilir. Bu dezavantajlarından ötürü maksillofasiyal bölgedeki patolojilerin değerlendirilmesinde üç boyutlu görüntüleme, oral ve maksillofasiyal radyolojide artan bir şekilde kullanılmaktadır. $4,8,9$

Çene lezyonlarının yaşa, cinsiyete, lokasyona göre dağılımları ve popülasyondaki görülme sıklıkları, farklı lezyon gruplarının ayırıcı tanısında klinisyenlere yardımcı olabilecek bulgulardır. Açıkgöz ve arkadaşları $^{10}$ tarafından 12350 hastayı içeren Türk popülasyonu üzerinde odontojenik ve non-odontojenik kistlerin prevelansları ve dağılımlarının incelendiği bir çalışmada lezyonlar kadınları erkeklerden \% 3.51 oranında daha fazla etkilemiştir. En çok rastlanılan odontojenik kist \% 54.7 oranıyla radiküler kist iken, daha sonra sırasıyla \% 26.6 oranıyla dentigeröz kiste, \% 13.7 oranıla rezidüel kiste, \% 3.3 oranıyla odontojenik keratokiste ve \% 0.2 oranı ile lateral periodontal kiste rastlanılmıştır. Non-odontojenik kist olarak sadece \% 1.5 oranıyla insiziv kanal kisti tespit edilmiştir. Görülme yaşlarına göre değerlendirildiğinde kistlere en yüksek oranda üçüncü dekatta rastlanılmıştır. Lezyonların görüldüğü çeneler açısından değerlendirilmesi sonucunda maksilla ve mandibulada görülme durumları bakımından istatistiksel olarak anlamlı bir fark bulunamamıştır. Geniş bir Türk popülasyonu üzerinde yapılan bu çalışmada, odontojenik keratokist olarak kistler içerisinde sınıflandırılan KOT bizim çalışmamızda tümör ve benzeri lezyonlar grubu içerisinde sınıflandırımıştır. Bu yüzden çalışmamızda rastlanılan lezyonlar içerisinde KOT radiküler kistlerden sonra sayıca

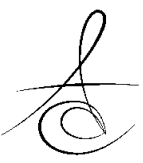


ikinci sırada yer almasına rağmen sınıflandırma farklıı̆ı sebebiyle Açıkgöz ve arkadaşlarının ${ }^{10}$ yaptığı çalışma ile bizim çalışmamız arasında farklııklar oluşmuştur. Bizim çalışmamızda kistler, erkeklerde kadınların yaklaşık iki katı oranında görülmüştür. Kistlerin en çok rastlanıldığı yaş aralı̆ı 0-20 ve 20-30 yaşlar arası olmuştur. Bizim çalışmamızda da en çok görülen kist $\% 71.6$ oranıyla radiküler kist olurken, onu $\% 6.8$ oranıyla dentigeröz kist takip etmiştir. Çalışmamızda rezidüel kiste ve lateral periodontal kiste ise; \% 2.7 oranında rastlanıımışır. Bizim çalışmamızla Açıkgöz ve arkadaşlarının $^{10}$ yaptığı çalışma arasında farklııkların olmasının sebebi lezyonların sınıflandırmasındaki farklılık dışında, Açıkgöz ve arkadaşlarının çalışmasında popülasyonu oluşturan hasta sayısının fazla olması ve bu çalışmanın sadece kist grubu lezyonları içermesi olabilir.

Meningaud ve arkadaşları ${ }^{11}$ tarafından Fransız popülasyonunda, 695 hasta üzerinde odontojenik kistlerin retrospektif olarak değerlendirildiği bir çalışmada, çalışmaya dahil edilen hastaların ortalama yaşı $41.8 \pm 15.8$ iken, erkek-kadın oranı ise; $1.86: 1^{\prime}$ di. Lezyonların görülme oranı mandibulada maksillanın üç katıydı. Bu çalışmada maksillada ve mandibulada tespit edilen lezyonlara çoğunlukla posterior bölgede rastlanılmıştır. Bizim çalışmamızda maksiller lezyonlar çoğunlukla anterior bölgede lokalizeyken, mandibular lezyonlar çoğunlukla posteriorda yerleşim göstermiştir.

Çenelerin odontojenik tümör ve tümör benzeri lezyonlarının değerlendirildiği bir çalışmada, 164 hastanın 91 (\% 55) tanesi kadın ve 73 (\% 44.5) tanesi erkekti. Hastaların ortalama yaşı 32.5 olmasına karşın, \% 30'u 18 yaşın altındaydı. Tümörlerin en çok rastlanıldığı bölge mandibulaydı. Histolojik incelemede 60 (\% 36.6) tane ameloblastomaya, 52 (\% 31.7) tane santral dev hücreli granülomaya, $2(\% \quad 1,2)$ tane adenomatoid odontojenik tümöre (AOT) rastlanılmıştı. ${ }^{12}$ Gana popülasyonu üzerinde prospektif olarak yapılan ve oro-fasiyal bölgede rastlanılan tümör ve tümör benzeri lezyonların değerlendirildiği 6 ylllık bir çalışmada, tümörlere tüm yaş gruplarında ve cinsiyette rastlanılmıştı. Benign non-odontojenik ve tümör benzeri lezyonların sayısı 47 (\% 26)'ydi. Bu gruptaki lezyonlardan fibro-osseöz lezyonların sayısı 25 (\% 53), dev hücreli granülomaların sayısı 3 (\% 6)'tü. ${ }^{13}$ Retrospektif olarak Çin popülasyonunda odontojenik tümörlerin değerlendirildiği bir çalışmada, 1642 lezyonun 1592 (\% 97)'si benign, 50 (\% 3) tanesi maligndi.
Ameloblastoma (\% 40.3) ve KOT (\% 35.8) en çok rastlanılan tümörlerdi. ${ }^{14}$ Bizim çalışmamızda tümör ve benzeri lezyonlar grubunda en çok rastlanılan lezyon $\% 61.2$ oranıly KOT, onun takibinde $\% 20.4$ oranıyla dev hücreli granüloma lezyonlarıydı. Çalışmamızda ossifying fibroma ve ameloblastomaya $\% \quad 4.1$ oranında, fibröz displaziye ise $\% 2$ oranında rastlanılmıştır. Lezyon tespit edilen hastaların görüldüğü yaş aralığı 7-72 yaştı. Lezyonların bulundukları çenelere göre dağılımları değerlendirildiğinde, hem kistler hem de tümör ve benzeri lezyonlara mandibulada daha fazla rastlanımıştı. Lezyonların lokasyonlarına göre dağıımının değerlendirilmesinde; kistler maksillada daha çok anterior bölgede yer alırken, mandibulada posterior bölgede; tümör ve benzeri gruptaki lezyonlar ise hem maksillada hem de mandibulada daha çok posterior bölgede yer almaktaydı.

Çenelerde rastlanılan kemik içi lezyonlar; çeşitli semptomlara sebebiyet verip, hastaların şikâyetleri sonucu yapılan klinik ve radyolojik muayene sonucunda tespit edilebilirken, asemptomatik olarak tesadüfi olarak da tespit edilebilirler. 2006 yllında ortodontik tedavi öncesi değerlendirme için, 496 hastadan alınan panoramik radyografilerde tesadüfi bulgu olarak anomali ve patoloji varlığını belirlemek için yapılan bir çalışmada yaklaşık \% 3 oranında hastada periapikal lezyon ve kist varlığı tespit edilmiştir. ${ }^{15} 2010$ yılında Macanovic ve arkadaşlar ${ }^{16}$ tarafından yapılan bir derlemede; travma panoramik radyografilerinde raporlama yapılırken, tesadüfi olarak patolojilerin tespit edilebileceği ve bu yüzden radyologların bu lezyonların klinik ve radyolojik bulguları konusunda bilinçli olmaları gerektiği vurgulanmışır. Bizim çalışmamızda 123 lezyonun $\% 61^{\prime} i$ hastaların yakınmaları sonucu tespit edilirken, \% 39'u hastaların herhangi bir şikâyeti olmadan, rutin klinik ve radyolojik muayene sonucunda tespit edilmiştir.

Ağrı ve şişlik; çene lezyonuna sahip hastaların en çok yakındığı problemlerin başında gelir. Bizim çalışmamızda lezyonların yarısından fazlası ağrıya sebebiyet verirken, şişliğin rastlandığı lezyonların oranı hem kistlerde hem de tümör ve benzeri lezyonlarda yaklaşık \% 30 olarak bulunmuştur. Palpasyonda hassasiyet ve fistül oluşumu; genellikle sekonder olarak enfekte olmuş lezyonların alveolar mukozayı etkilemesinden kaynaklanır. Çalışmamızda fistül oluşumuna kistlerde \% 17.6 oranında rastlanırken, tümör ve benzeri lezyonlarda \% 6.1 oranında, palpasyonda 
hassasiyete ise; kistlerde \% 35.1 oranında, tümör ve benzeri lezyonlarda \% 34.7 oranında rastlanılmıştır. Çalışmamızda en çok rastladığımız klinik bulgu lezyonla ilişkili dişlerde oluşan vitalite kaybı olurken; lenfadenopati, ağız açıklığında kısıtlılık gibi bulgulara \% 5'in altında bir oranla daha az olarak rastlanılmıştır. Kistler ve tümörlerin tespitinde, ayırıcı tanısında ve tedavi planlamasında lezyonla ilişkili dişlerin vitalitelerinin değerlendirilmesi yarar sağlayabilecek önemli bir tanısal testtir. Odontojenik kaynaklı iltihabi kistler, vital olmayan bir dişten kaynaklanırlar. Ayırıcı tanıda vitalite testi göz önünde bulundurulması gereken bir durumdur. Bizim çalışmamızda lezyonla ilişkili dişte vitalite kaybına sebep olma durumu kistlerde \% 64.9 oranındayken, tümör ve benzeri lezyonlarda ise; \% 36.7 oranında bulunmuştur. Kistlerle ilişkili dişlerde vitalite kaybının fazla bulunmasının sebebi çalışma popülasyonumuzda radiküler kistlerin varlığının fazla olması olabilir. Fasiyal asimetri ve parestezi genellikle büyük boyutlara ulaşan tümoral lezyonlarda karşımıza çıkan bulgulardır. Çalışmamızda fasiyal asimetriye kistlerde \% 13.5 oranında, tümöral lezyonlarda \% 20.4 oranında rastlanıırken; paresteziye kistlerde \% 1.4 oranında, tümoral lezyonlarda \% 14.3 oranında rastlanılmıştır. Fasiyal asimetri ve parestezinin tümoral lezyonlardaki görülme oranının kistlerden fazla olduğu göze çarpmaktadır.

Çenelerde görülen lezyonlar çevrelerinde ilişkide bulundukları dokularda değişikliklere sebep olabilirler. Lezyon tarafından etkilenen dişlerde yer değiştirme, mobilite ve diş köklerinde rezorpsiyon gibi değişiklikler lezyonun karakteristiğini belirleme konusunda bizlere yardımcı olabilir. Dişlerde yer değiştirme, yavaş büyüyen ve büyük boyutlara ulaşan lezyonlarda gözlenen bir bulgudur. Çalışmamızda kistlerin \% 5.4'ü, tümoral lezyonların \% 16.3'ü dişlerde yer değiş̧ikliğine sebep olmuştur. Diş köklerinde rezorpsiyon genellikle kronik, yavaş büyüyen benign tümörler ve kistlerde rastlanılır. Çalışmamızda kistlerin \% 4.1'i, tümoral lezyonların \% 14.3'ü diş köklerinde rezorpsiyona sebep olmuştur. Klinik muayenede mobil bir dişe rastlanıması, diş kökünü ve çevresini etkileyen patolojik bir durumun varlığına işaret edip, dişle ilişkili bir çene lezyonunun tespit edilmesine yardımcı olabilir. Çalışmamızda kistlerin \% 14.9'u, tümoral lezyonların \% 24.5'i lezyonla ilişkili dişlerde mobiliteye sebep olmuştur.
Dişlerin gömük kalması çok sık rastlanılan bir durumdur. En çok gömük kalan dişler yirmi yaş dişleri, kaninler ve sürnümerer dişlerdir. Çenelerde görülen kistler ve tümörler içerisinde gömük diş barındırabilir. Hint popülasyonunda 4133 hastadan elde edilen panoromik radyografiler üzerinde tespit edilen 5486 adet gömük yirmi yaş dişinin kist ya da tümör gibi lezyonla ilişkisinin varlığını değerlendiren bir çalışmada gömük yirmi yaş dişleriyle ilişkili 134 (\% 2.24) tane kist ve 63 (\% 1.6) tane tümöre rastlanmıştır. ${ }^{17}$ Bizim çalışmamızda kistlerin \% 12.2'sinde, tümoral lezyonların \% 32.7'sinde lezyonla ilişkili gömük dişe rastlanılmıştır.

Sonuç olarak; çene kemiklerinde sıklıkla görülen intraosseöz lezyonların tespitinde, ayırıcı tanısında ve tedavi planlamasında klinik muayene ve direkt radyografilerle yapılan radyolojik muayenenin önemli bir yeri vardır. Çenelerde; rutin muayene sonucu elde edilen bulgularla tesadüfi olarak kemik patolojileri tespit edilebilir. Bu sebeple diş hekimleri rutin klinik ve radyolojik muayenenin önemi konusunda bilinçli olmalıdırlar.

\section{KAYNAKLAR}

1. Kramer IRH, Pindborg JJ, Shear M. The WHO Histological typing of odontogenic tumours. A commentary on the second edition. Cancer, 1992, 70: 2988-94.

2. 2auria L, Curi MM, Chammas MC, Pinto DS, Torloni $\mathrm{H}$. Ultrasonography evaluation of bone lesions of the jaw. Oral Surg Oral Med Oral Pathol Oral Radiol Endod, 1996, 82: 351-7.

3. Sumer AP, Danaci M, Ozen Sandikci E, Sumer M, Celenk P. Ultrasonography and Doppler ultrasonography in the evaluation of intraosseous lesions of the jaws. Dentomaxillofac Radiol, 2009, 38: 23-7.

4. White SC, Pharoah MJ. Oral Radiology: Principles and Interpretation. Baskı. Elsevier Health Sciences, 2008.

5. Regezi JA, Sciubba JJ, Jordan RCK. Oral Pathology: Clinical Pathologic Correlations. Baskı. Elsevier Health Sciences, 2012.

6. Miloro M, Peterson LJ. Peterson's Principles of Oral and Maxillofacial Surgery. Baskı. People's Medical Publishing House-USA, 2012: 23. 
7. Harorlı $A$, Akgül HM, Yılmaz AB, Bilge OM, Dağıstan $S$, Çakur B, Çağlayan F, Miloğlu Ö, Sümbüllü MA. Ağız, Diş ve Çene Radyolojisi. 1. Baskı. İstanbul, Nobel Tıp Kitapevleri, 2014.

8. Danacı M. Mandibula ve Maksilla Radyolojisi. Turkiye Klinikleri Journal of Radiology Special Topics, 2008, 1: 38-44.

9. Vandenberghe $B$, Jacobs R, Bosmans H. Modern dental imaging: a review of the current technology and clinical applications in dental practice. Eur Radiol, 2010, 20: 2637-55.

10. Acikgoz A, Uzun-Bulut E, Ozden B, Gunduz K. Prevalence and distribution of odontogenic and nonodontogenic cysts in a Turkish population. Med Oral Patol Oral Cir Bucal, 2012, 17: 108-15.

11. Meningaud JP, Oprean N, Pitak-Arnnop P, Bertrand JC. Odontogenic cysts: a clinical study of 695 cases. J Oral Sci, 2006, 48: 59-62.

12. Stypulkowska J. [Odontogenic tumors and neoplastic-like changes of the jaw bone. Clinical study and evaluation of treatment results]. Folia Med Cracov, 1998, 39: 35-141.

13. Parkins GE, Armah GA, Tettey Y. Orofacial tumours and tumour-like lesions in Ghana: a 6-year prospective study. $\mathrm{Br}$ ] Oral Maxillofac Surg, 2009, 47: 550-4.

14. Jing $W$, Xuan $M$, Lin $Y$, Wu $L$, Liu $L$, Zheng $X$, Tang W, Qiao J, Tian W. Odontogenic tumours: a retrospective study of 1642 cases in a Chinese population. Int J Oral Maxillofac Surg, 2007, 36: 20-5.

15. Bondemark $L$, Jeppsson $M$, Lindh-Ingildsen $L$, Rangne K. Incidental findings of pathology and abnormality in pretreatment orthodontic panoramic radiographs. Angle Orthod, 2006, 76: 98-102.

16. Macanovic M, Gangidi S, Porter G, Brown S, Courtney $D$, Porter J. Incidental bony pathology when reporting trauma orthopantomograms. Clin Radiol, 2010, 65: 842-9.

17. Patil S, Halgatti V, Khandelwal S, Santosh BS, Maheshwari S. Prevalence of cysts and tumors around the retained and unerupted third molars in the Indian population. J Oral Biol Craniofac Res, 2014, 4: 82-7.

\section{Yazışma Adresi:}

Dr. İbrahim Şevki BAYRAKDAR

Atatürk Üniversitesi Diş Hekimliği Fakültesi Ağız, Diş ve Çene Radyolojisi ABD 25240 Erzurum / TÜRKIYE

Telefon numarası: +90 4422311805

Fax numarası: +90 4422360945

E-mail: ibrahimsevkibayrakdar@gmail.com 